\title{
Radiological Doses and Risk Assessment of NORM Scrap Metal by Using RESRAD-RECYCLE Computer Code
}

\author{
Amaal A. Tawfik, Eman M. Ahmed \\ Radiation Protection Department, Nuclear and Radiological Regulatory Authority, Nasr City, Cairo, Egypt \\ Email: emanmassoud@yahoo.com
}

Received 20 January 2014; revised 23 February 2014; accepted 5 March 2014

Copyright (C) 2014 by authors and Scientific Research Publishing Inc.

This work is licensed under the Creative Commons Attribution International License (CC BY). http://creativecommons.org/licenses/by/4.0/

(c) $\underset{\mathrm{EY}}{\mathrm{C}}$ Open Access

\begin{abstract}
In this work the radiological dose and risks resulting from recycling of radioactive contaminated NORM scrap metal that produced from one of oil and gas production companies in Egypt, were determined by using RESRAD-RECYCLE computer code. Two scenarios were used: the first was the workers' scenario, while the second was end-use product scenario. Workers' scenario was used in this study for evaluating the dose and risk to workers who process recycled materials. This scenario focused on the transport of radioactive NORM scrap metal from the place of origin to the smelter (scrap delivery step). Scenarios for six different workers were included under the scrap delivery step: two workers scrap cutter, two workers scrap loader, and two workers scrap truck driver. The values for each scenario were specified on the basis of processing 200 tons of NORM scrap metal. Because these operations occur before melting of the metal, mass and radionuclide partitioning factors were not applied in the scrap metal delivery step. The radionuclide concentration of the NORM scrap metal was used directly in the dose calculation. The maximum doses received from direct external exposure to all radio nuclides during cutter/sorter, scrap truck driver and unloading of scrap metals were 2.14E-04, 1.4E-06 and 1.86E-05 $(\mathrm{mSv})$ respectively. The excess cancer risks for all radio nuclides during cutter/sorter of scrap metals reached 1.25E-07. Radiation exposures incurred by the scrap unloaders and scrap cutters/sorters were greater than those incurred by the other workers for their closer exposure distances and longer time.
\end{abstract}

\section{Keywords}

NORM Scrap Metals; Risk Assessment; Dose Assessment; RESRAD-RECYCLE; Radioactive Waste

\section{Introduction}

There are many incidents worldwide of radioactively contaminated material becoming incorporated into the 
scrap metal chain. The radioactive material tends to originate from one of three sources: orphan radioactive sources, naturally occurring radioactive material (or NORM) and nuclear materials. In particular, NORM contaminated dusts may be generated during handling or processing of scrap and breathed into the body. Steel and other non-ferrous components can become contaminated with "low specific activity" scale (LSA) arising from the handling or processing of naturally occurring radioactive materials. This often arises in the oil and gas extraction industries. There are generally rigorous procedures in place to monitor and decontaminate items prior to disposal as scrap material.

Radionuclide, present in NORM scrap metals giving off ionizing radiation which can interact with human cells, is hazard that may caused for human and environment depend on: radionuclide type, its activity, the radiation it emits, how that radiation interacts with the human body, whether the radioactive material becomes incorporated into the body, exposure time and the distance from the source [1]. However the risks can be grouped into two categories: External radiation, Sources such as Cs-137, Co-60, Ra-226, Ir-192 give off powerful gamma rays which can pass through air over great distances (100 s meters), or Internal radiation radionuclide can be incorporated into the body by ingestion, inhalation and through the skin (absorption, cuts and grazes) [2].

Orphan radioactive sources typically come from redundant industrial equipment, such as process gauges incorporating radioactive sources. They are likely to contain, but are not restricted to, cesium (Cs-137), cobalt (Co-60) or radium (Ra-226) encapsulated in a stainless steel capsule to form a "sealed source”. Industrial radiography sources such as iridium (Ir-192) and depleted uranium (U-238) source containers may also be encountered. Redundant or waste radioactive sources from medical applications, and old dials and gauges luminesce with Ra-226 have also found their way into the scrap metal chain. Naturally occurring radioactive material (or NORM) or low specific activity (LSA) scale-NORM typically contains uranium (U-238), thorium (Th232) and their associated radioactive decay products. They can accumulate as a slightly radioactive scale on the inside of chemical plant which processes certain chemical feed stocks (e.g. zircon sand, phosphates), oil and gas. Scrap metal containing enhanced levels of these naturally occurring radionuclides can find their way into the metal supply chain. Nuclear material-material originating from the nuclear fuel cycle has occasionally been found in the scrap supply chain. Whilst most countries with a nuclear industry have very rigorous controls over the release of potentially contaminated scrap metal for recycling, lack of controls in some countries has resulted in high value scrap such as stainless steel or copper contaminated with radioactive material [3].

Bulk NORM commodities, residues and wastes can be transported as liquids (oil), and solids. Therefore requirements for the safe transport of these bulk materials can vary widely. The International Atomic Energy Agency (IAEA) has published a number of documents that are relevant to the transport of radioactive material [4]-[7].

Transport of NORM is unlikely to lead to significant external exposures to members of the public, because of the very short exposure time involved. Most of the gamma radiation produced by the radioactive decay of naturally occurring radio nuclides is relatively low energy radiation, and a considerable fraction of the radiation released from bulk NORM material is absorbed in the material (self-absorption) [8]. Truck drivers are generally enclosed in metal cabs during transport, which provides some shielding from the gamma radiation emanating from the material being transported. However, workers such as truck drivers can be exposed for much longer periods.

\section{Materials and Methods}

\subsection{RESRAD-RECYCLE Computer Code}

The RESRAD-RECYCLE family of codes has been developed by the Argonne National Laboratories to assess the radiological doses and associated cancer risks for workers and the public, resulting from exposure to radio nuclides. RESRAD-RECYCLE assesses the radiological doses resulting from the recycle of contaminated material or the reuse of contaminated equipment. It considers external exposure, inhalation and ingestion pathways. The model includes 20 worker scenarios and 11 consumer product scenarios. The recycle process is subdivided into the following activities:

- initial transport of scrap,

- smelting, 
- transport to fabrication plants,

- product fabrication,

- use of consumer product.

The code takes into account the emissions through the stack during melting, the management of the bag house filters, and the utilization of the slag for various public or consumer products such as roads, bridges, parking lots, etc. Other examples of consumer products considered are frying pans, appliances, rooms, offices, and home furniture, etc. The code can also assess scenarios with controlled products like shield blocks and radiation waste containers. The exposure scenarios developed, the pathways considered and exposure parameter used are based on information from technical literature. The RESRAD-RECYCLE code has a nuclide database of 54 radio nuclides. Those with a half-life of less than one year are excluded, except for Mn-54 and Zn-65. The results of the assessments are presented in tabulations of individual, collective and cumulative committed effective doses, based on the scenarios, pathways and radionuclide.

\subsection{Scenario Description}

To facilitate dose calculations, the geometry of the radiation source, exposure distance between the source and the worker, and the time span of each operation were developed on the basis of the real operations [9].

Exposure scenarios were developed to account the various operations conducted during the transportation process.

The truck drivers transported the NORM scrap metal from Oil and Gas Production Company located in Eastern Desert to one of the steel company located in $10^{\text {th }}$ Ramadan City, Egypt. Scenarios for three different workers are included under the scrap delivery step: a scrap cutter, a scrap loader, and a scrap truck driver. The values for each scenario are specified on the basis of processing 200 ton of NORM scrap metal. Because these operations occur before the metal is melted, mass and radionuclide partitioning factors were not applied in the scrap metal delivery step. The radionuclide concentration of the NORM scrap metal is used directly in the dose calculation.

\subsection{Source Geometries and Exposure Parameters}

Table 1 lists the source geometry and exposure parameters used by RESRAD-RECYCLE for dose calculations. For the scrap truck driver scenario, the external radiation was considered to be attenuated by the truck cab, which had a density of $7.86 \mathrm{~g} / \mathrm{cm}^{3}$ and a thickness of $0.3 \mathrm{~cm}$.

\section{Measurements at the Site}

\subsection{Background Measurements}

Background measurements were done at the site during June 19-20 2007 and it was ranged from 0.05 to 0.07 $\mu \mathrm{Sv} / \mathrm{h}$.

Background dose measurement was performed during $24 \mathrm{~h}$ with 10 area TLD dosimeters in the scrap yard. Two persons working with scrap had TLD dosimeters for $24 \mathrm{~h}$, with a detection and report limit of $0.08 \mathrm{mSv}$.

Table 1. Source geometry and exposure parameters.

\begin{tabular}{|c|c|c|c|c|c|c|c|c|c|c|c|}
\hline $\begin{array}{l}\text { Worker } \\
\text { scenario }\end{array}$ & $\begin{array}{c}\text { Source } \\
\text { geometry }\end{array}$ & $\begin{array}{l}\text { Mass } \\
\text { (t) }\end{array}$ & $\begin{array}{l}\text { Density } \\
\left(\mathrm{g} / \mathrm{cm}^{3}\right)\end{array}$ & $\begin{array}{c}\text { Thickness } \\
\text { (cm) }\end{array}$ & $\begin{array}{l}\text { Radius } \\
\text { (cm) }\end{array}$ & $\begin{array}{l}\text { Distance } \\
\text { (cm) }\end{array}$ & $\begin{array}{l}\text { Time } \\
\text { (h) }\end{array}$ & $\begin{array}{c}\text { Source material } \\
\text { for the external } \\
\text { pathway }^{\mathrm{a}}\end{array}$ & $\begin{array}{c}\text { Source material } \\
\text { for the internal } \\
\text { pathway }^{\mathrm{a}}\end{array}$ & $\begin{array}{l}\text { Dust } \\
\text { loading } \\
\left(\mathrm{g} / \mathrm{m}^{3}\right)\end{array}$ & $\begin{array}{c}\text { Number of } \\
\text { workers }\end{array}$ \\
\hline $\begin{array}{l}\text { Scrap truck } \\
\text { driver }\end{array}$ & $\begin{array}{l}1 \text { full } \\
\text { cylinder }\end{array}$ & 3.3 & 0.126 & 400 & 145 & 150 & 1 & NORM scrap & NORM scrap & $1 \times 10^{-5}$ & 2 \\
\hline $\begin{array}{c}\text { Scrap } \\
\text { unloader }\end{array}$ & $\begin{array}{c}1 \text { full } \\
\text { cylinder }\end{array}$ & 3.3 & 0.126 & 400 & 145 & 150 & 3 & NORM scrap & NORM scrap & $1 \times 10^{-5}$ & 2 \\
\hline $\begin{array}{c}\text { Scrap } \\
\text { cutter/sorter }\end{array}$ & $\begin{array}{l}1 \text { full } \\
\text { cylinder }\end{array}$ & 3.3 & 0.126 & 400 & 145 & 150 & 10 & NORM scrap & NORM scrap & $1 \times 10^{-5}$ & 2 \\
\hline
\end{tabular}

${ }^{\mathrm{a}}$ Radionuclide concentration in the NORM specified scrap materials used in the dose calculations for the various workers scenarios. 


\subsection{Activity Measurements}

AD-6 instrument was used to measure the exposure dose, while area contamination monitor was used for area contamination. The background radiation level in the cultivated area and in the scrap yard was detected and in the range of 200 - 300 cps.

Higher radiation levels (700 - $800 \mathrm{cps}$ ) were recorded in and outside the storage. The main probable reason, the building was built from slag from earlier times (a hundred or more years ago). One point also registered 600 cps at a location behind the wall in the scrap yard. Portable multi-channel analyzers could be used to identify specific radio nuclides. Radiometric analyses of different samples from contaminated NORM scrap metal were carried out using a high resolution gamma ray spectrometric system. The system was comprised of high purity germanium detector (HPGe) with $81 \mathrm{~cm}^{3}$ sensitive volume. The detector has an energy resolution of $2.2 \mathrm{KeV}$ FWHM for the $1332.5 \mathrm{KeV}$ of gamma energy of Co-60. To reduce environmental gamma background radiation, the detector was shielded with lead bricks of thickness 5 to $10 \mathrm{~cm}$. A lining of 2-mm-thick copper followed by 2-mm-thick aluminum was made to absorb the $\mathrm{x}$ rays from lead and copper.

\section{Results}

\subsection{NORM Concentration in Scale Scrap Metal}

NORM concentration in ten samples from hard scale scrap metal was determined using high purity germanium detector (HPGe) and the results are shown in Table 2. From this table it is clear that the most common radionuclide were Ra-226, Ra-228, Ra-224 and K-40. The following radionuclide from the U-238 series was identified: Th-234, U-234, Th-230, Ra-226, Rn-222, Pb-210, Bi-210, Po-210. From the Th-232 series we have: Ra-228, Th-228, Ra-224.

Highest level of radium isotopes (Ra-226, Ra-228, Ra-224) were observed from hard scale samples. The analysis result of radium activity was ranged between 178 and 46 Bq/g, while the concentration of K-40 ranged from 6 to $16 \mathrm{~Bq} / \mathrm{g}$. These results may be due to the co-precipitated radium matrix is not thermodynamically stable at reducing conditions which may enable a fraction of the radium to eventually be released to the environment [10].

\subsection{Activity Level from Oil Separator Storage Tanks and Other Surface Equipments}

Sludge that containing NORM are produced from the cleaning of oil separator, storage tanks and other surface equipments. The contaminated scrap metals with sludge that has Ra-226, Ra-228, Ra-224 and K-40 as shown in Table 3. From this table it was clear that these wastes contained less activity than the hard scale.

The analysis result of radium activity was ranged between 108 and $38 \mathrm{~Bq} / \mathrm{g}$, while the concentration of K-40 ranged from 5 to $11 \mathrm{~Bq} / \mathrm{g}$.

Table 2. Radionuclide concentration in hard scale scrap metal.

\begin{tabular}{ccccc}
\hline Sample no. & \multicolumn{2}{c}{ NORM Concentration (Bq/g) } & K-40 \\
\cline { 2 - 5 } $\mathbf{1}$ & Ra-226 & Ra-228 & Ra-224 & $13 \pm 2$ \\
$\mathbf{2}$ & $97 \pm 3$ & $81 \pm 1$ & $55 \pm 3$ & $11 \pm 1$ \\
$\mathbf{3}$ & $132 \pm 1$ & $77 \pm 1$ & $63 \pm 1$ & $16 \pm 2$ \\
$\mathbf{4}$ & $174 \pm 1$ & $101 \pm 2$ & $67 \pm 2$ & $7 \pm 1$ \\
$\mathbf{5}$ & $163 \pm 2$ & $65 \pm 1$ & $46 \pm 1$ & $9 \pm 1$ \\
$\mathbf{6}$ & $88 \pm 1$ & $89 \pm 1$ & $53 \pm 1$ & $12 \pm 1$ \\
$\mathbf{7}$ & $103 \pm 2$ & $109 \pm 4$ & $48 \pm 2$ & $13 \pm 2$ \\
$\mathbf{8}$ & $99 \pm 1$ & $111 \pm 1$ & $51 \pm 1$ & $6 \pm 1$ \\
$\mathbf{9}$ & $118 \pm 2$ & $84 \pm 2$ & $57 \pm 1$ & $8 \pm 1$ \\
\hline
\end{tabular}


Table 3. NORM concentration in different samples scrap metal contaminated by sludge.

\begin{tabular}{ccccc}
\hline \multirow{2}{*}{ Sample no. } & \multicolumn{2}{c}{ NORM Concentration $\mathbf{( B q} / \mathbf{g})$} & Ra-224 & K-40 \\
\cline { 2 - 4 } & Ra-226 & Ra-228 & $38 \pm 1$ & $11 \pm 0.9$ \\
2 & $81 \pm 1$ & $67 \pm 1$ & $51 \pm 1$ & $10 \pm 1$ \\
3 & $102 \pm 2$ & $57 \pm 1$ & $48 \pm 1$ & $8 \pm 1$ \\
4 & $108 \pm 1$ & $91 \pm 3$ & $35 \pm 2$ & $7 \pm 0.9$ \\
5 & $83 \pm 2$ & $44 \pm 1$ & $55 \pm 1$ & $6 \pm 0.8$ \\
6 & $67 \pm 1$ & $60 \pm 2$ & $39 \pm 1$ & $10 \pm 0.8$ \\
7 & $93 \pm 1$ & $88 \pm 2$ & $49 \pm 1$ & $9 \pm 0.8$ \\
9 & $79 \pm 3$ & $63 \pm 1$ & $60 \pm 3$ & $5 \pm 0.8$ \\
\end{tabular}

\subsection{External Radiation Exposures, Inhalation and Ingestion}

External radiation exposures, excluding background levels, inhalation and ingestion were shown in the Tables 4-6. Among the three exposure pathways analyzed, radiation exposure from the external radiation pathway was far more significant than radiation exposure from the two internal radiation pathways (inhalation and ingestion). Radiation exposures incurred by the scrap unloaders and scrap cutters/sorters were greater than those incurred by the other workers because of the closer exposure distances and longer exposure times experienced by the scrap unloaders and scrap cutters/sorters. The doses received from Ra-226 during scrap cutter/sorter were greater than that those received during unloader and truck driver.

Exposure parameters and source dimensions used in dose calculations were derived from the RESRADRECYCLE default values, which were modified to accommodate the smaller through put and smaller furnace capacity. For dose calculations, RESRAD-RECYCLE used their own dose conversion factors and partitioning factors.

Because of the low level of contamination in the scrap metal, radiation exposures measured in the melting facility could not be differentiated from background level. Therefore, no measurement data were available to validate the calculation results obtained with the models.

The maximum dose received from direct external exposure to K-40, Ra-226 and Ra-228 during cutter/sorter of scrap metals is represented in Figures 1-3. These figures show a relation between the total effective doses $(\mathrm{mSv})$ with the time (years) that received as a result of direct exposure. The maximum dose received from direct external exposure to K-40, Ra-226 and Ra-228 during cutter/sorter of scrap metals are 6E-06, 6.5E-04 and $2.8 \mathrm{E}-04 \mathrm{mSv} / \mathrm{y}$ respectively and these results similar to that published in Argonne National Laboratory (1995, 1996) [11] [12]. Figures 4 and 5 show that the total effective dose received from Ra-228 and Ra-226 with ingrowths progeny during cutter/sorting of scrap metals. From these figures it is clear that the total effective dose received from Ra-228, Ra-226 with ingrowths progeny are $2.8 \mathrm{E}-04$ and $6.5 \mathrm{E}-04 \mathrm{mSv} / \mathrm{y}$ respectively, and this is may be due to external gamma exposure and radon inhalation [10].

The excess cancer risks for all radionuclides and all pathways during cutter/sorter of scrap metals reached to 1.39E-06 and this is shown in Figure 6.

The maximum dose received to the scrap truck driver during transportation process is shown in Figure 7. This figure shows that the doses received from Ra-226 and Ra-228 is $5.8 \mathrm{E}-05$ and $1.3 \mathrm{E}-04$ respectively, while the maximum dose received during unloading process from Ra-226 and Ra-228 is $4.6 \mathrm{E}-05$ and $8.2 \mathrm{E}-05$ respectively as shown in Figure 8. Radiation exposures incurred by the scrap unloaders and scrap cutters/sorters were greater than those incurred by the other workers because of the closer exposure distances to gamma rays that produced from scrap metals contaminated with NORM and longer exposure times experienced by the scrap unloaders and scrap cutters/sorters [13].

It is clear from the radioactive dose assessment results that the total annual exposure dose to the whole body is less than the limit; $0.25 \mathrm{mSv}$ (10 CFR 61). This means that cutter/sorting and transportation process is safe. 
Table 4. Calculation and measured doses (mSv) for scrap truck driver scenario.

\begin{tabular}{cccc}
\hline Radionuclides & External Radiation & Inhalation & Ingestion \\
\hline Ra-226 & $5.8 \mathrm{E}-05$ & $1.09 \mathrm{E}-11$ & $1.01 \mathrm{E}-11$ \\
Ra-228 & $1.3 \mathrm{E}-04$ & $1.11 \mathrm{E}-14$ & $2.98 \mathrm{E}-14$ \\
Ra-224 & $3.21 \mathrm{E}-8$ & $4.10 \mathrm{E}-16$ & $6.41 \mathrm{E}-15$ \\
K-40 & $1.98 \mathrm{E}-07$ & $1.06 \mathrm{E}-13$ & $1.98 \mathrm{E}-12$ \\
Total (Individual) & $1.46 \mathrm{E}-06$ & $1.59 \mathrm{E}-11$ & $1.97 \mathrm{E}-11$ \\
Total (Collective) & $1.94 \mathrm{E}-06$ & $2.95 \mathrm{E}-11$ & $3.42 \mathrm{E}-11$ \\
\hline
\end{tabular}

Table 5. Calculation and measured doses (mSv) for scrap unloader scenario.

\begin{tabular}{cccc}
\hline Radionuclides & External Radiation & Inhalation & Ingestion \\
\hline Ra-226 & $4.6 \mathrm{E}-05$ & $1.49 \mathrm{E}-10$ & $1.01 \mathrm{E}-10$ \\
Ra-228 & $8.2 \mathrm{E}-05$ & $1.61 \mathrm{E}-13$ & $2.98 \mathrm{E}-13$ \\
Ra-224 & $2.21 \mathrm{E}-08$ & $3.30 \mathrm{E}-15$ & $6.41 \mathrm{E}-14$ \\
K-40 & $2.38 \mathrm{E}-07$ & $1.76 \mathrm{E}-12$ & $1.98 \mathrm{E}-11$ \\
Total (Individual) & $1.86 \mathrm{E}-05$ & $1.09 \mathrm{E}-10$ & $1.97 \mathrm{E}-10$ \\
Total (Collective) & $1.84 \mathrm{E}-05$ & $2.75 \mathrm{E}-10$ & $3.42 \mathrm{E}-10$ \\
\hline
\end{tabular}

Table 6. Calculation and measured doses (mSv) for scrap cutter/sorter scenario.

\begin{tabular}{cccc}
\hline Radionuclides & External Radiation & Inhalation & Ingestion \\
Ra-226 & $6.5 \mathrm{E}-04$ & $1.13 \mathrm{E}-9$ & $2.141 \mathrm{E}-9$ \\
Ra-228 & $2.8 \mathrm{E}-04$ & $124 \mathrm{E}-14$ & $1.38 \mathrm{E}-11$ \\
Ra-224 & $3.26 \mathrm{E}-07$ & $2.64 \mathrm{E}-11$ & $4.51 \mathrm{E}-13$ \\
K-40 & $6 \mathrm{E}-06$ & $1.10 \mathrm{E}-9$ & $1.98 \mathrm{E}-11$ \\
Total (Individual) & $2.76 \mathrm{E}-04$ & $2.65 \mathrm{E}-9$ & $2.33 \mathrm{E}-9$ \\
Total (Collective) & $2.14 \mathrm{E}-04$ & 2 \\
\hline
\end{tabular}



Figure 1. Effective dose received from exposure to K-40 during cutter/ sorting. 




Figure 2. Effective dose received from exposure to Ra-226 during cutter/ sorting.

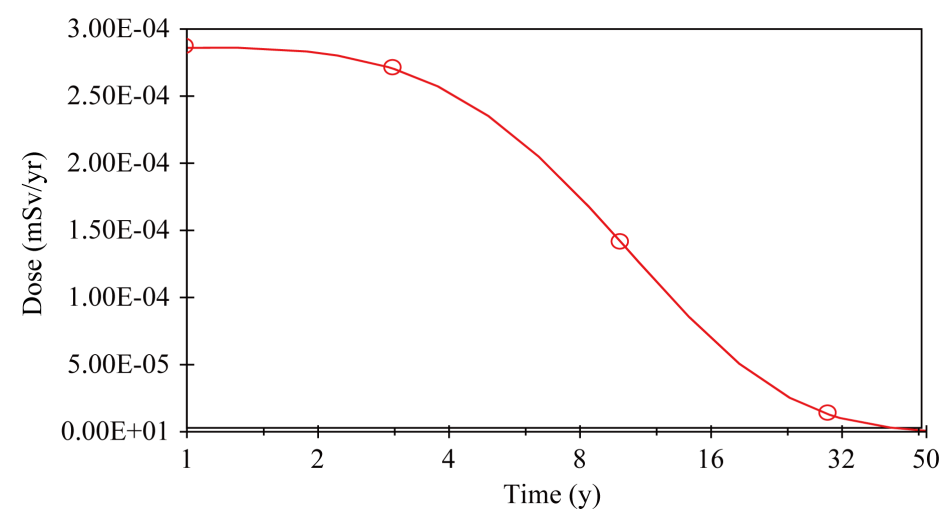

Figure 3. Effective dose received from exposure to Ra-228 during cutter/ sorting.

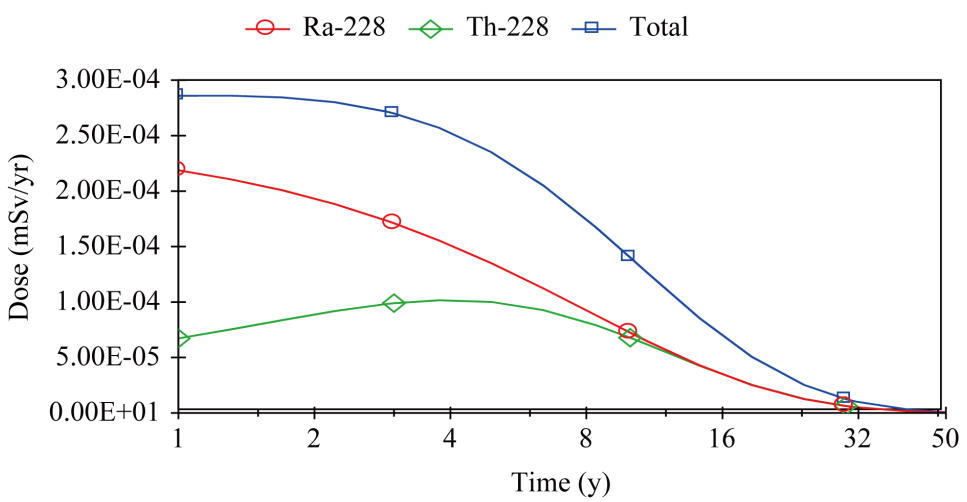

Figure 4. Total effective dose received from Ra-228, within growth progeny during cutter/sorting.

\section{Conclusion}

The aim of this work is to determine the radiological dose and risks resulting from recycling of radioactive contaminated NORM scrap metal produced from one of oil and gas productions in Egypt by using RESRAD-Recycle computer code. From this study we can conclude that the radiation exposures incurred by the scrap unloaders and scrap cutters/sorters were greater than those incurred by the other workers because of the closer exposure distances and longer exposure time experienced by the scrap unloaders and scrap cutters/sorters. The doses received from Ra-226 during scrap cutter/sorter were greater than those received during unloader and 


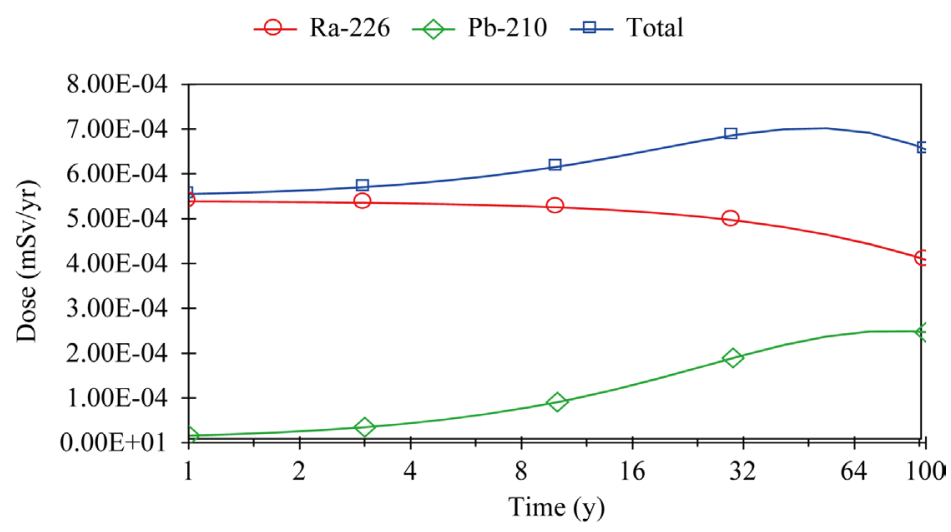

Figure 5. Effective dose received from Ra-226 within growth progeny during cutter/sorting.

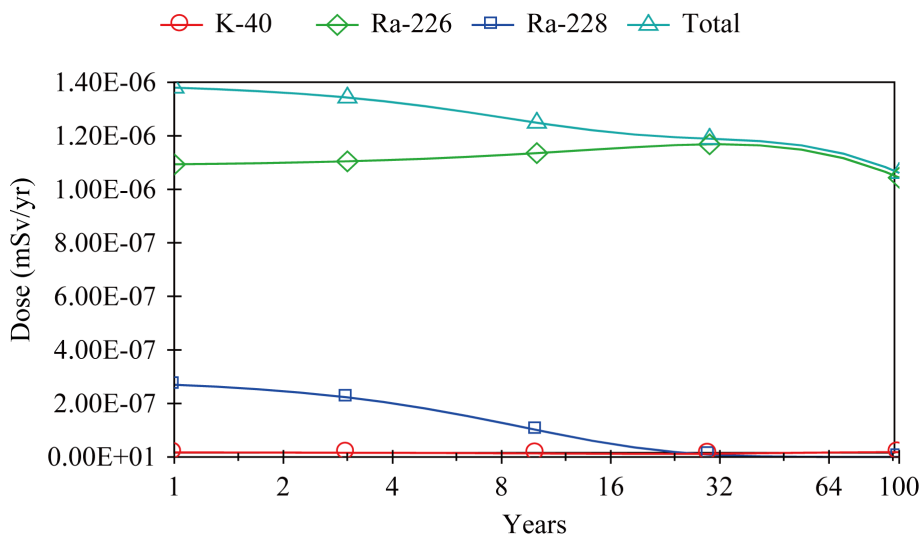

Figure 6. Cancer risk from exposure to NORM scrap metal contaminated by Ra-226, Ra-228 and K-40 during cutter/sorting.

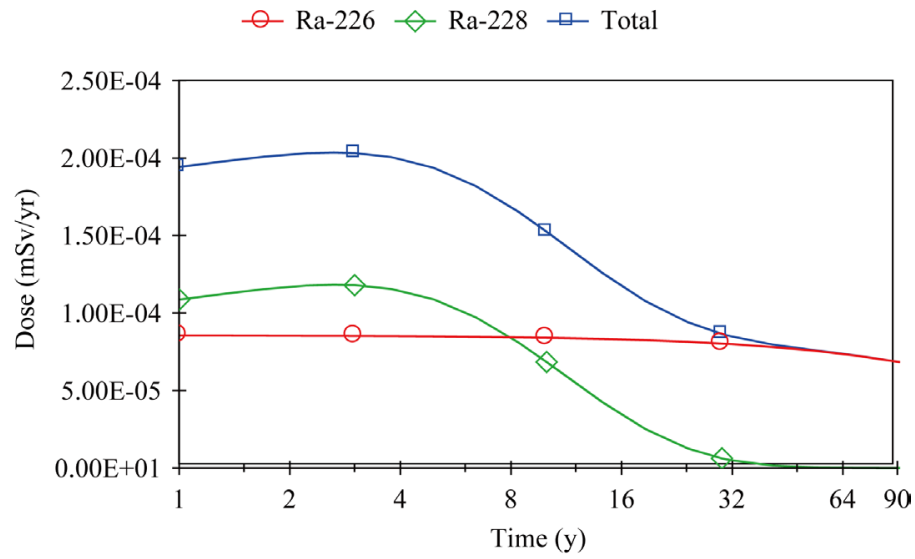

Figure 7. Total effective dose received from all radionuclides during transportation process for the scrap truck driver.

truck driver. The excess cancer risks for all radio nuclides and all pathways during cutter/sorter of scrap metals reached 1.39E-06.

This paper concerning evaluating doses and risks from the transport of radioactive NORM scrap metal from the place of origin (scrap delivery step, Egyptian Eastern desert) to the steel company ( $10^{\text {th }}$ Ramadan City, Egypt). The NORM scrap metal was shipped to the steel company in a 20-foot-long container. The maximum 


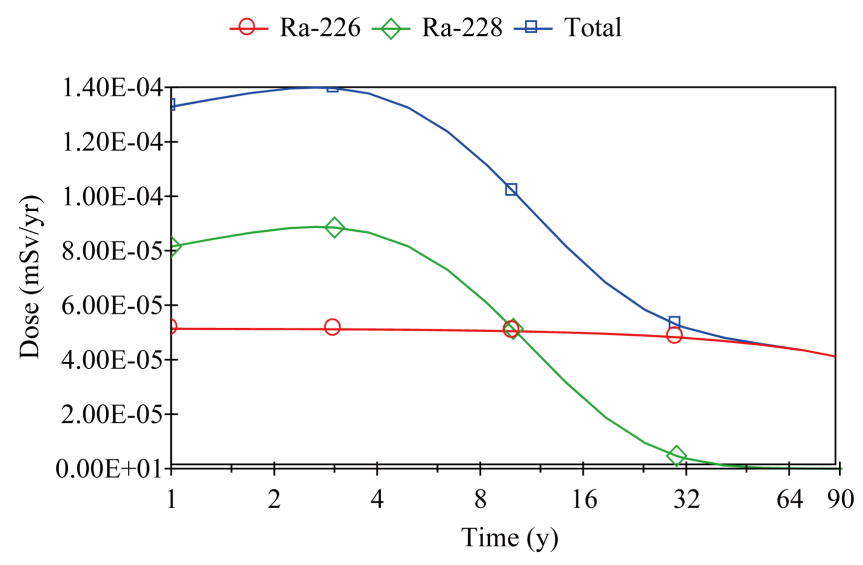

Figure 8. Total effective dose received from Ra-226, Ra-228 and total radionuclides during unloaders of scrap metals.

dose rate measured on the outside of the container was $0.2 \mathrm{mSv} / \mathrm{h}$. Radionuclide-specific measurements (made from outside the package) indicated an average radioactivity concentration of $109 \mathrm{~Bq} / \mathrm{g}$.

\section{References}

[1] IAEA Safety Standard Series No. Ts-G-1.1 (ST-2) (2005) IAEA Regulations for the Safe Transport of Radioactive Material, IAEA, Vienna.

[2] Smith, K.P., Blunt, D.L., Williams, G.P. and Tebes, C.L. (1996) Radiological Dose Assessment Related to Management of Naturally Occurring Radioactive Materials Generated by the Petroleum Industry. ANL/EAD-2, Argonne National Laboratory, Argonne.

[3] Environmental Protection Agency (1993) Draft Diffuse NORM-Waste Characterization and Preliminary Risk Assessment. US Office of Radiation and Indoor Air, Washington DC; Pergamon Press, Oxford.

[4] IAEA Safety Standards Series Safety Guide No. TS-G-1.3 (IAEA, 2007).

[5] IAEA Safety Standards Series Safety Guide No. TS-G-1.2 (ST-3) (IAEA, 2002).

[6] IAEA Safety Standards Series Safety Requirements No. TS-R-1 2005 (IAEA, 2005).

[7] IAEA Safety Standards Series Safety Guide No. TS-G-1.1 (ST-2) (IAEA, 2002).

[8] Tomasko, D., Elcock, D., Veil, J. and Caudle, D. (1997) Risk Analyses for Disposing Nonhazardous Oil Field Wastes in Salt Caverns. Prepared for US Department of Energy, Office of Fossil Energy, Argonne National Laboratory, Argonne.

[9] Australian Radiation Protection and Nuclear Safety Agency, Safety Guide (2008) Management of Natural Occurring Radioactive Materials. Radiation Protection Series Publication No. 15.

[10] Rajaretnam, G. and Spitz, H.B. (2000) Effect of Leachability on Environmental Risk Assessment for Naturally Occurring Radioactive Materials in Petroleum Oil Fields.

[11] Nieves, L.A. (1995) Evaluation of Radioactive Scrap Metal Recycling. 1995 ANIJEAIYTM-50, Argonne National Laboratory, Argonne.

[12] Smith, K.P., Blunt, D.L., Williams, G.P. and Tebes, C.L. (1996) Radiological Dose Assessment Related to Management of Naturally Occurring Radioactive Materials Generated by the Petroleum Industry. mAD-2, Argonne National Laboratory, Argonne. http://dx.doi.org/10.2172/414355

[13] Hamlat, M.S., Djeffal, S. and Kadi, H. (2001) Assessment of Radiation Exposures from Naturally Occurring Radioactive Materials in the Soil and Gas Industry. Applied Radiation and Isotopes, 55, 1.

http://dx.doi.org/10.1016/S0969-8043(01)00042-2 